\title{
Effect of anti-smoking advertisements on Turkish adolescents
}

E. Unal, ${ }^{7}$ M.E.Gokler, ${ }^{1}$ S. Metintas ${ }^{7}$ and C. Kalyoncu ${ }^{7}$

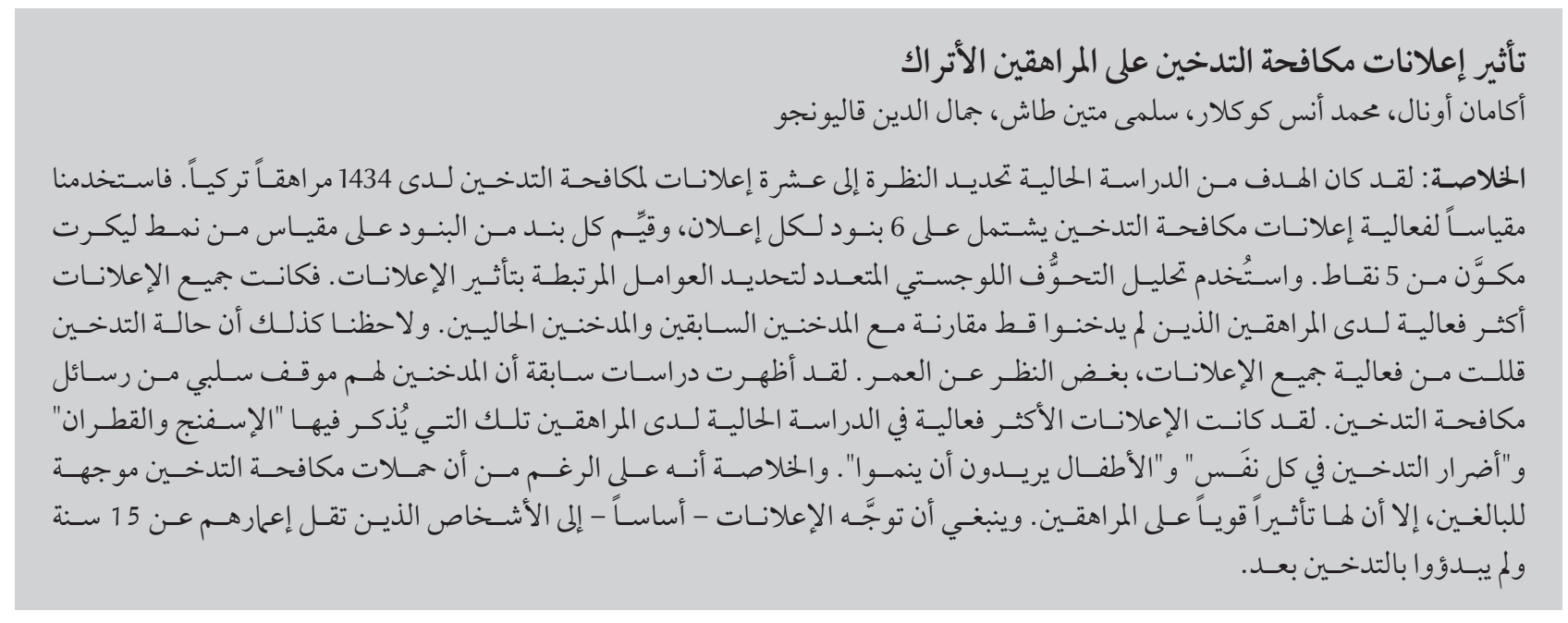

ABSTRACT The aim of the present study was to determine the perception of 10 anti-smoking advertisements in 1434 Turkish adolescents. We used the Effectiveness of the Anti-smoking Advertisements Scale, which included 6 items for each advertisement; each item was assessed on a 5-point Likert-type scale. Multiple logistic regression analysis was used to determine the factors associated with the impact of the advertisements. All the advertisements were more effective for adolescents who had never smoked compared to ex-smokers and current smokers. We also noted that, regardless of age, smoking status decreased the effectiveness of all the advertisements. Previous studies have shown that smokers have a negative attitude towards anti-smoking messages. In the present study, the most effective advertisements among adolescents were those with "Sponge and tar", "Smoking harms in every breath" and "Children want to grow". In conclusion, although anti-smoking campaigns are targeted towards adults, they also have a strong influence on adolescents. The main target population for advertisements should be individuals aged $<15$ years who have not yet started smoking.

\section{Influence des publicités antitabac sur des adolescents turcs}

RÉSUMÉ La présente étude avait pour objectif de déterminer la façon dont 10 publicités antitabac étaient perçues par 1434 adolescents turcs. Nous avons utilisé l'échelle d'efficacité des publicités antitabac qui inclut six items par publicité, chaque item étant évalué sur une échelle de Likert reposant sur un système de cinq points. L'analyse de régression logistique multiple a été utilisée afin de déterminer les facteurs associés à l'impact des publicités. Toutes les publicités étaient plus efficaces auprès des adolescents qui n'avaient jamais fumé qu'auprès des anciens fumeurs ou des fumeurs actuels. Nous avons également noté que, indépendamment de l'âge, le statut tabagique avait une influence sur l'efficacité de toutes les publicités. Les études précédentes ont montré que les fumeurs ont une attitude négative face aux messages antitabac. Dans la présente étude, les publicités ayant démontré la plus grande efficacité parmi les adolescents étaient celles avec «L'éponge et le goudron », "Fumer nuit à chaque respiration », et « Les enfants veulent pouvoir grandir ». En conclusion, bien que les campagnes antitabac ciblent les adultes, elles ont également une forte influence sur les adolescents. La cible principale des publicités dans la population devrait être les individus âgés de moins de 15 ans qui n'ont pas encore commencé à fumer. 


\section{Introduction}

Tobacco use continues to be theleading cause of preventable death worldwide (1). The World Health Organization (WHO) adopted the Framework Convention on Tobacco Control (FCTC) in 2003 and highlighted the need for an effective programme to protect people from the damage associated with tobacco use (2).

The fight against tobacco-related deaths includes methods with wellestablished effectiveness. In 2008, the WHO defined criteria to assess tobacco control methods. These criteria, also known as Monitoring, Protect, Offer, Warn, Enforce and Raise (MPOWER), ensure that the implementations defined in the FCTC can be achieved (3).

According to the WHO report, Turkey has achieved significant success in the implementation of these criteria and in the control of tobacco use (2). The WHO Report on the Global Tobacco Epidemic 2013 indicated that the smoking rate in Turkey was $10.2 \%$ in males, $5.3 \%$ in females and $8.4 \%$ in adolescents (4). In Turkey, $33.0 \%$ of the population is under the age of 18 years. Although the smoking rate among adults decreased by $4.1 \%$ between 2008 and 2012, no significant decrease was found in smoking rates among adolescents (1).

In fulfilling implementation of the WHO criteria, a national media campaign was launched in Turkey with the slogans of "Smoke-free air" and "Protect your air". Anti-smoking advertisements involving visual media were one of the tools used in this campaign. Advertisements have been shown to be effective for quitting smoking; ensuring the motivation needed and maintaining cessation $(5,6)$. The impact of the advertisements on individuals varies based on the keynote messages of advertisement and the sociodemographic characteristics of the audience (7). It is important to evaluate the impact of the messages given via advertisements on smokers and on adolescents who do not currently smoking but are at risk of starting. Many adolescents use cigarettes out of curiosity, to reduce stress, to feel grown up or to experience the camaraderie of being in a group (8). Moreover, the tobacco industry lies about the health risks of smoking and uses all communication channels including social media to direct children and adolescents towards using tobacco $(2,9-11)$. The impact of the messages given by advertisements on the adolescent age group is important, although there are few studies on this issue (12).

The aim of the present study was to determine the perception of antismoking advertisements in adolescents in Turkey.

\section{Methods}

\section{Research area}

The study was performed in Eskisehir, which is a province in Turkey with a population of $\sim 800000$ in 2014. There are 130000 adolescents living in Eskisehir (13). After 8 years of basic education, the students are selected by an examination to the Anatolian or vocational high schools.

\section{Study group}

An estimated study sample size of at least 1225 individuals was calculated based on an estimated $15 \%$ of the adolescents being not affected by the anti-smoking advertisements (14), a $2 \%$ of margin of error and a $95 \%$ confidence interval $\left[\right.$ Sample Size $=1.96^{2} \times p \times(1-p) / d^{2}$, were $\mathrm{p}=$ probability and $\mathrm{d}=$ sample error]. To select the study sample, we used a 2-stage stratified cluster sampling procedure. There are two provinces in the city centre (urban) and 12 at the

\begin{tabular}{ll}
\hline $\begin{array}{l}\text { Table } 1 \text { Description of ADs } \\
\text { ADs }\end{array}$ & $\begin{array}{l}\text { Describes the discomfort resulting from smoking to a smoker and his/her family } \\
\text { Rejuvenation in all aspects (V1) } \\
\text { Smoking in daily living (V2) } \\
\text { Smoke-free air (V3) }\end{array}$ \\
COPD and regret (V4) & $\begin{array}{l}\text { Emphasises smoke-free air in a taxi } \\
\text { Describes the history of a heavy smoker who quit smoking as a result of noticing } \\
\text { the harmful effects of cigarettes on him/her and his/her family }\end{array}$ \\
A bad example of a father (V5) & $\begin{array}{l}\text { Describes the harmful effects of passive smoking and the bad influence of a } \\
\text { smoking father on his child }\end{array}$ \\
Grandfather and grandson (V6) & $\begin{array}{l}\text { Describes the role of a grandson in leading his grandfather to quit smoking } \\
\text { Describes the effects of a smoking-related disease, COPD, on quality of life }\end{array}$ \\
Smoking harms in every breath (V8) & $\begin{array}{l}\text { Simulates the damage induced by smoking in the lungs } \\
\text { Describes the mental and physical harmful effects of smoking towards children } \\
\text { Children want to grow (V9) } \\
\text { Sponge and tar (V10) }\end{array}$ \\
& $\begin{array}{l}\text { Describes the cigarette-induced pathological changes and the accumulation of tar } \\
\text { in the lungs }\end{array}$ \\
\hline
\end{tabular}

The first, fifth and eighth videos can be viewed at http://tv.thsk.saglik.gov.tr/index.php/component/contushdvideoshare/player/15/11, and the others can be viewed at http://www.youtube.com/user/burakfilm/videos?view=0\&flow=grid\&sort=p. AD=anti-smoking advertisements; COPD =chronic obstructive pulmonary disease. 
peripheral area (semirural) of Eskisehir. The schools were classified as Anatolian and vocational high schools by their educational curricula. One province (Odunpazari) and two schools were randomly selected from the city centre. One province (Sivrihisar) and two schools were randomly selected from the semirural area. A total of 1434 Class 1-3 students present during the school visits were included.

\section{Study design}

In Turkey, according to "Law of The Prevention and Control of Harm from Tobacco Products", television and radio organizations must broadcast advertisements about the health risks associated with the use of tobacco products and other substances for at least 90 minutes monthly (15). A research team examined all the smoking-related advertisements on television and classified them according to their topics. Then, among the advertisements under the same topic, the 10 with the highest scores were identified and randomly arranged (Table 1).

\section{Study procedure}

The first part of our questionnaire focused on the sociodemographic characteristics and smoking status of the students. The second part consisted of the Effectiveness of the Anti-smoking Advertisements Scale (EAAS), which included 6 items for each anti-smoking advertisement. Cronbach's alpha value, of the scale ranged between 0.792 and 0.891 for each advertisement, with a median of 0.841 showing good reliability (16). The content of the scale was validated by expert opinion. The EAAS items assessed the clarity, persuasiveness, reminder, stop and think, scaring and dissuasive features of the ADs. Each item was assessed on a 5-point Likerttype scale, with scores of $5=$ strongly agree, $4=$ agree, $3=$ don't know, $2=$ disa gree, and $1=$ strongly disagree. The total score was calculated by summing the

\begin{tabular}{|c|c|}
\hline Sociodemographic & $n^{\mathrm{a}}(\%)$ \\
\hline \multicolumn{2}{|l|}{ Gender } \\
\hline Male & $611(42.6)$ \\
\hline Female & $823(57.4)$ \\
\hline \multicolumn{2}{|l|}{ Age (yr) } \\
\hline 15 & $580(40.4)$ \\
\hline 16 & $496(34.6)$ \\
\hline 17 & $358(25.0)$ \\
\hline \multicolumn{2}{|l|}{ Residence } \\
\hline Rural & $542(37.8)$ \\
\hline Urban & $892(62.2)$ \\
\hline \multicolumn{2}{|l|}{ Socioeconomic status } \\
\hline Poor & $126(9.6)$ \\
\hline Moderate & $854(60.4)$ \\
\hline Good & $420(30.0)$ \\
\hline \multicolumn{2}{|l|}{ Smoking status } \\
\hline Never smoked & $896(62.8)$ \\
\hline Initiator & $211(15.0)$ \\
\hline Smoker & $313(22.2)$ \\
\hline \multicolumn{2}{|l|}{ Close friend smokes } \\
\hline Yes & $926(64.6)$ \\
\hline No & $508(35.4)$ \\
\hline \multicolumn{2}{|c|}{ Adult in household smokes } \\
\hline Yes & $943(65.8)$ \\
\hline No & $491(34.2)$ \\
\hline
\end{tabular}

${ }^{a}$ There were some differences in the totals due to unanswered questions.

score of each item, with a possible score between 6 and 30 points.

After obtaining the necessary permission from the school administration and consent form from parents of students, the students were gathered in a meeting hall at a specified date and time. After providing information about the study and obtaining verbal consent, the students were placed in suitable locations where they could not see or influence each other. All students were grouped by school and each group consisted of 30-40 students. The sessions were managed by the researchers. The students were asked to fill out the first part of the questionnaire in 10 minutes under supervision. In the second part of the questionnaire, each advertisement was shown on a screen, and all groups of students were asked to fill out the EAAS for each advertisement. There were 1-minute intervals between each advertisement.

It would have been difficult to assess the impact of advertisements viewed on television during daily living. Thus, we showed a video recording to remind the students about the advertisement; then, the reactions of the students were assessed. This process enabled us to compare the reactions of the students to different video recordings.

\section{Measurements}

Students who had never smoked, even a puff, were classified as never-smokers; 


\begin{tabular}{|c|c|c|c|}
\hline ADs & $\begin{array}{c}\text { Median } \\
\text { (IQR 25-75\%) }\end{array}$ & Mean (SD) & $\begin{array}{l}\text { Affected by the AD } \\
(\%)\end{array}$ \\
\hline Rejuvenation in all aspects & $21(18-24)$ & $20.83(5.19)$ & 70.6 \\
\hline Smoking in daily living & $21(18-25)$ & $20.69(5.55)$ & 68.2 \\
\hline Smoke-free air & $22(19-26)$ & $21.71(5.68)$ & 69.7 \\
\hline COPD and regret & $22(18-26)$ & $21.66(5.57)$ & 68.2 \\
\hline A bad example of a father & $22(18-26)$ & $21.64(5.74)$ & 67.2 \\
\hline Grandfather and grandson & $22(18-25)$ & $21.14(5.55)$ & 66.3 \\
\hline Non-smoking is happiness & $22(18-25)$ & $21.33(5.67)$ & 66.6 \\
\hline Smoking harms in every breath & $26(22-30)$ & $24.81(5.45)$ & 83.0 \\
\hline Children want to grow & $25(22-28)$ & $24.19(5.12)$ & 81.2 \\
\hline Sponge and tar & $27(23-30)$ & $25.36(5.54)$ & 81.0 \\
\hline
\end{tabular}

$A D=$ anti-smoking advertisements; $C O P D=$ chronic obstructive pulmonary disease; $I Q R=$ interquartile range; $S D=$ standard deviation.

those who had attempted to smoke with at least one puff but who were not currently smoking were classified as initiators; and those who were currently using cigarettes were classified as smokers (17).

Smoker close friends were defined as having at least one close friend who used cigarettes, and a smoker adult family member was defined as having a mother and/or father who used cigarettes. The family income level was classified as low, moderate or high.

\section{Statistical analysis}

The data were analysed using IBMSPSS version 20.0. Cronbach's alpha, was calculated for each anti-smoking advertisement using the reliability analysis.

The EAAS scores were expressed as the mean (SD) and median (interquartile range). A new data set was created to compare the EAAS scores for the advertisements. Kruskal-Wallis and Bonferroni corrected Mann-Whitney $U$ tests were used to compare the median scores between the advertisements and to determine the differences between the groups. $x^{2}$ test was used for the comparison of frequency data.

To determine the impact level for each advertisement, a dummy variable with a normal distribution and a mean value of 0.0001 was derived from the EAAS scores using the Minitab programme. The knowledge scores of the students were classified into two clusters through a k-means clustering analysis and by using the dummy variable. The scores calculated in reference to these cluster features were then used in the ROC analysis to determine the cut-off point, and the impact score cut-off value was determined for each advertisement.

Multiple logistic regression analysis was used to determine the factors associated with the impact of the advertisements. Odds ratios and 95\% confidence intervals were calculated for the variables associated with each advertisement.

\section{Ethical approval}

This study was approved by the Ethics Committee of Eskisehir Osmangazi University, Medicine Faculty, NonDrug Clinical Research Committee (14.05.2013 Number: 80558721/184 Decision no: 17).

\section{Results}

Of the 1434 students included in the study, 823 (57.4\%) were female, 580 (40.4\%) were 15 years old, 496 (34.6\%) were 16 years old (Table 2 ). The overall smoking prevalence was $22.2 \%$, and the smoking prevalence by gender was $32.5 \%$ and $17.3 \%$ among male and female students, respectively $(P<0.001)$. The smoking prevalence among high school students was not different statistically between rural and urban areas $(P=0.284)$. The smoking prevalence was found to increase with age (18.6\%, $21.7 \%$ and $28.1 \%$ for students aged 15,16 and 17 years, respectively) $(P=$ 0.008 ).

The rate of being affected by the advertisements ranged between $66.3 \%$ and 83.0\% (Table 3). The highest score was reported for the advertisement "Smoking harms in every breath", followed by "Sponge and tar" and "Children want to grow" $(P<0.001)$. The cut-off point of the scale was calculated as 21.5 . The area under the curve was 0.693 . The advertisements with a score greater than the cut-off point were considered to have an impact on the audience.

In our multiple logistic regression model (Table 4), the only factor associated with the effectiveness of all the advertisements was smoking status. Initiators or smokers were less affected by all the advertisements compared to the never-smokers. Except for the "Smoke-free air" and "Children want to grow" advertisements, the effectiveness decreased with increasing student age. The rates of being affected 


\begin{tabular}{|c|c|c|c|c|c|c|c|}
\hline \multirow[t]{2}{*}{ ADs } & Residence & Gender & Age & $\begin{array}{c}\text { Socioeconomic } \\
\text { status }\end{array}$ & $\begin{array}{c}\text { Adult in } \\
\text { household } \\
\text { smokes }\end{array}$ & $\begin{array}{l}\text { Close friend } \\
\text { smokes }\end{array}$ & Smoking status \\
\hline & OR $(95 \% \mathrm{Cl})$ & OR $(95 \% \mathrm{CI})$ & OR $(95 \% \mathrm{Cl})$ & OR $(95 \% \mathrm{Cl})$ & OR $(95 \% \mathrm{Cl})$ & OR $(95 \% \mathrm{Cl})$ & OR $(95 \% \mathrm{Cl})$ \\
\hline $\begin{array}{l}\text { Rejuve-nation } \\
\text { in all aspects }\end{array}$ & - & - & $\begin{array}{l}0.81^{*} \\
(0.69-0.94)\end{array}$ & $\begin{array}{l}0.74^{*} \\
(0.60-0.91)\end{array}$ & $\begin{array}{l}0.76^{*} \\
(0.58-0.98)\end{array}$ & $\begin{array}{l}0.67^{*} \\
(0.51-0.89)\end{array}$ & $\begin{array}{l}0.69^{* *} \\
(0.60-0.81)\end{array}$ \\
\hline $\begin{array}{l}\text { Smoking in } \\
\text { daily living }\end{array}$ & - & $\begin{array}{l}1.37^{*} \\
(1.06-1.76)\end{array}$ & $\begin{array}{l}0.76^{* *} \\
(0.65-0.88)\end{array}$ & $\begin{array}{l}0.79^{*} \\
(0.64-0.97)\end{array}$ & - & $\begin{array}{l}0.67^{*} \\
(0.51-0.88)\end{array}$ & $\begin{array}{l}0.71^{* *} \\
(0.61-0.82)\end{array}$ \\
\hline Smoke-free air & $\begin{array}{l}1.31^{*} \\
(1.01-1.70)\end{array}$ & - & - & $\begin{array}{l}0.79^{*} \\
(0.64-0.98)\end{array}$ & $\begin{array}{l}0.75^{*} \\
(0.58-0.97)\end{array}$ & $\begin{array}{l}0.64^{*} \\
(0.48-0.84)\end{array}$ & $\begin{array}{l}0.64^{* *} \\
(0.55-0.74)\end{array}$ \\
\hline $\begin{array}{l}\text { COPD and } \\
\text { regret }\end{array}$ & - & - & $\begin{array}{l}0.83^{*} \\
(0.71-0.96)\end{array}$ & - & - & - & $\begin{array}{l}0.72^{* *} \\
(0.62-0.83)\end{array}$ \\
\hline $\begin{array}{l}\text { A bad example } \\
\text { of a father }\end{array}$ & - & - & $\begin{array}{l}0.86^{*} \\
(0.74-0.99)\end{array}$ & $\begin{array}{l}0.73^{*} \\
(0.60-0.90)\end{array}$ & - & - & $\begin{array}{l}0.75^{* *} \\
(0.65-0.87)\end{array}$ \\
\hline $\begin{array}{l}\text { Grandfather } \\
\text { and grandson }\end{array}$ & - & - & $\begin{array}{l}0.83^{*} \\
(0.71-0.96)\end{array}$ & $\begin{array}{l}0.76^{*} \\
(0.62-0.93)\end{array}$ & $\begin{array}{l}0.77^{*} \\
(0.60-0.99)\end{array}$ & - & $\begin{array}{l}0.68^{* *} \\
(0.58-0.78)\end{array}$ \\
\hline $\begin{array}{l}\text { Non-smoking is } \\
\text { happiness }\end{array}$ & - & - & $\begin{array}{l}0.80^{*} \\
(0.69-0.92)\end{array}$ & $\begin{array}{l}0.78^{*} \\
(0.64-0.96)\end{array}$ & & - & $\begin{array}{l}0.79^{* *} \\
(0.68-0.91)\end{array}$ \\
\hline $\begin{array}{l}\text { Smoking harms } \\
\text { in every breath }\end{array}$ & - & - & $\begin{array}{l}0.80^{*} \\
(0.67-0.96)\end{array}$ & - & - & - & $\begin{array}{l}0.73^{* *} \\
(0.62-0.87)\end{array}$ \\
\hline $\begin{array}{l}\text { Children want } \\
\text { to grow }\end{array}$ & - & $\begin{array}{l}1.67^{* *} \\
(1.24-2.26)\end{array}$ & - & - & - & - & $\begin{array}{l}0.71^{* *} \\
(0.60-0.84)\end{array}$ \\
\hline Sponge and tar & - & $\begin{array}{l}1.52^{*} \\
(1.12-2.05)\end{array}$ & $\begin{array}{l}0.75^{* *} \\
(0.63-0.89)\end{array}$ & - & - & - & $\begin{array}{l}0.73^{* *} \\
(0.62-0.86)\end{array}$ \\
\hline
\end{tabular}

${ }^{*} P<0.05 ;{ }^{* *} P<0.001$.

$A D=$ anti-smoking advertisements; $C I=$ confidence interval; $C O P D=$ chronic obstructive pulmonary disease; $O R=$ odds ratio

by the advertisements in the age 15 and 17 years groups were as follows: 65.6-75.5\% (V1); 61.5-73.3\% (V2); 64.0-73.4\% (V4); 66.6-72.4\% (V5); 62.9-71.0\% (V6); 63.2-73.0\% (V7); 80.6-86.7\% (V8) and $80.3-87.4 \%$ (V10). The effectiveness of the "Smoking in daily living", "Children want to grow" and "Sponge and tar" advertisements were more pronounced in female than male adolescents. The rates of being affected by the advertisements in male and female adolescents were as follows: $62.4-72.2 \%$ (V2); 74.8-86.4\% (V9) and 78.0-87.5\% (V10). The "Smoke-free air" advertisement was more effective on students living in urban areas compared with those living in rural areas. Socioeconomic status was associated with the effectiveness of the advertisements, with the highest three EAAS scores and the "COPD and regret" advertisement. The effectiveness of the advertisements decreased with the socioeconomic level. However, the effectiveness of the "Rejuvenation in all aspects", "Smoke-free air" and "Grandfather and grandson" advertisements decreased among the students whose mother and/or father smoked, while the effectiveness of the "Rejuvenation in all aspects", "Smoking in daily living" and "Grandfather and grandson" advertisements decreased among the students whose close friends were smokers.

\section{Discussion}

In this study, the anti-smoking advertisements "Smoking harms in every breath", followed by "Sponge and tar" and "Children want to grow" were most effective in adolescents. Therefore, determining adolescents' perception of smoking is crucial because tobacco use usually begins in adolescence (18). Adolescents have specific characteristics and risks for smoking addiction. Therefore, youthoriented anti-smoking campaigns should be initiated without delay.

The smoking rate in the study group appeared to be higher than that in the general population in Turkey, which might have resulted from including adolescents aged between 15 and 17 years and because the rate of smoking initiation is high in this age group. Nearly $90 \%$ of cigarette smokers first tried smoking by age 18 years (19). In light of this information, our study group had a high rate of attempting to smoke and a high risk of smoking initiation.

In the present study, the "Sponge and tar" advertisement was most effective among the adolescents. This advertisement describes smoking-induced pathological changes and tar accumulation in the lungs. The next most effective advertisements were "Smoking harms in every breath", which describes the lung damage caused by smoking, and 
"Children want to grow", which uses the theme that cigarettes have a negative influence on child growth. In the "Sponge and tar" advertisement, an experimental model was used to demonstrate smoking-induced accumulation of tar in the lungs that were simulated by a sponge, and the amount of tar accumulation in a year was demonstrated. The "Smoking harms in every breath" advertisement simulated the course of cigarette smoke reaching the lungs and demonstrated how the smoke fills the lungs and penetrates the tissues, resulting in fragmentation of the alveoli. Both these advertisements aimed to demonstrate visually, graphically and audibly the damage caused by cigarettes to the organs and tissues. It is possible that adolescents might have been influenced by the themes, particularly in the presentation and visual quality of these advertisements. Cotter et al. have demonstrated that the "Sponge and tar" advertisement provides information for adolescents regarding the damage caused by smoking and is effective in providing motivation to quit smoking (20). Another study has reported that the videos using experimental and visual methods to describe organ and tissue damage are more effective in terms of making viewers feel uncomfortable and message acceptance compared to videos including the smoking-related experiences of smokers (7).

The third most effective advertisement, "Children want to grow", describes the harmful effects of smoking on children and was found to be more effective than videos that described the past experiences of smokers. This might have been because the students realized that children view their parents as role models, and may acquire unhealthy behaviours such as smoking or be exposed to passive cigarette smoke from their parents, resulting in mental, social and physical damage. This opinion among adolescent non-smokers can help identify the target population for anti-smoking campaigns. Pechmann et al. reported that the anti-smoking messages for parents of the adolescent age group increased the effectiveness of the campaign (21).

None of the advertisements that were effective were related to the longterm outcomes of smoking. It is important to focus on this discovery when preparing anti-smoking advertisements for young people. Pechmann et al. have also reported that the causes of the associated risks should be the focus of the advertisements rather than the associated health risks and long-term serious outcomes (21).

In the present study, all of the antismoking advertisements were more effective for never-smokers than exsmokers and current smokers. It was also important that, regardless of age, smoking behaviour decreased the effectiveness of all the advertisements. The literature has shown that smokers have a negative attitude towards anti-smoking messages (22). Therefore, it would be more beneficial to show specific advertisements to individuals in an age group in which smoking behaviour has not begun. Videos with greater effectiveness should be used to prevent attempts by smokers to ignore the advertisements.

Also influence of most of the antismoking advertisements decreased with increasing age. In a study by Vardavas et al., the effectiveness of the health warnings on the tobacco packages was found to decrease with increasing age in adolescents (23). Likewise, Biener and Sieger have found a decreased effectiveness of advertisements with increasing age in adolescents (24). This trend might occur because, with increasing age, adolescents usually attempt smoking because they equate cigarettes with being an adult, and cigarettes are perceived to represent social status. It is known that the tobacco industry particularly targets individuals aged 12-17 years, with the aim of influencing positive attitudes and behaviour towards tobacco in adolescents (19).
The association of age with the effect of advertisements in adolescents may be related to the dose-duration-response effect of the manipulation of the industry on adolescents.

Women represent $\sim 20 \%$ of the 1 billion smokers in the world and the prevalence of tobacco use among women is increasing in developed and developing countries (25). Women with economic freedom in developed countries smoke at nearly the same rate as men (26). However, the increase of smoking among women has been attributed not only to social factors and to increasing economic freedom, but also to the marketing strategies of the tobacco industry for women (27). The tobacco industry emphasises the independence and attractiveness of women and targets vulnerable adolescent women by equating cigarettes with independence, elegance, body weight control, culture and power (28). In the present study, the advertisement describing smoking-related difficulties in daily living (V2), such as smelling bad, had a greater effect on women than on men. This association might occur because women usually perceive their external environment in greater detail than men. However, the advertisements about the harmful effects of smoking on children (V9) also had a greater effect on women $(29,30)$.

The higher effectiveness found for the "Smoke-free air" advertisement in urban compared with rural areas might have occurred because adolescents living in urban areas are usually more exposed to smoking-related restrictions in city life compared with those living in rural areas. We emphasized that, compared with adolescents living in rural areas, those living in urban areas can easily access locations for social interaction that encourage smoking behaviour.

In our study, the lower effectiveness of the anti-smoking advertisements on individuals with low socioeconomic status might be related to the higher global prevalence of smoking among 
such individuals (31). However, there was no difference in socioeconomic level among the adolescents affected by the three most effective advertisements, which suggests that those advertisements should be used more intensively in countries with evident differences in income levels, such as Turkey.

Having a mother and/or father or close friends who smoke usually leads to adolescents trying smoking (32). In the present study, both situations resulted in a decreased effectiveness of the "Rejuvenation in all aspects" and "Grandfather and grandson" advertisements, which may be a result of less empathy felt by these adolescents.

The major limitations in this study were the cross-sectional study design and the fact that the adolescents selfassessed the effects of the anti-smoking advertisements. Additionally, the effectiveness of the advertisements was assessed in an unnatural manner by showing the videos in an experimental setting. Moreover, the adolescents were not asked how many times they had watched the advertisements on television.

In conclusion, although the antismoking campaigns were targeted toward the adult population, they also had a large influence on adolescents. However, campaigns including messages for adolescents should be prepared. The main target population for these new anti-smoking advertisements should be non-smoker individuals aged $<15$ years. Because there were significant differences in the effectiveness of the advertisements, the theme, content, characteristics, presentation and specific features for adolescents should be considered.

\section{Acknowledgements}

Our main thanks go to the hundreds of students who participated in this study. We also thank the other participants and colleagues. Finally, we thank the interns who contributed to this study through the acquisition of the data.

\section{Funding: None.}

Competing interests: None declared.

\section{References}

1. Global health risks: mortality and burden of disease attributable to selected major risks. Geneva: World Health Organization; 2009 (http://www.who.int/healthinfo/global_ burden_disease/GlobalHealthRisks_report_full.pdf, accessed 31 August 2016).

2. WHO report on the global tobacco epidemic, 2013. Enforcing bans on tobacco advertising, promotion and sponsorship. Geneva: World Health Organization; 2013 (http://apps. who.int/iris/bitstream/10665/85380/1/9789241505871_eng. pdf?ua=1, accessed 31 August 2016).

3. MPOWER in action. Defeating the global tobacco epidemic (http://www.who.int/tobacco/mpower/publications/ mpower_2013.pdf?ua=1, accessed 23 December 2013).

4. Erguder T, Polat H, Arpad C, Khoury RN, Warren CW, Lee J, et al. Linking Global Youth Tobacco Survey (GYTS) data to tobacco control policy in Turkey - 2003 and 2009. Cent Eur J Public Health. 2012 Mar;20(1):87-91. PMID:22571026

5. Biener L, McCallum-Keeler G, Nyman AL. Adults' response to Massachusetts anti-tobacco television advertisements: impact of viewer and advertisement characteristics. Tob Control. 2000 Dec;9(4):401-7. PMID:11106710

6. Durkin S, Brennan E, Wakefield M. Mass media campaigns to promote smoking cessation among adults: an integrative review. Tob Control. 2012 Mar;21(2):127-38. PMID:22345235

7. Wakefield M, Bayly M, Durkin S, Cotter T, Mullin S, Warne C; International Anti-Tobacco Advertisement Rating Study Team. Smokers' responses to television advertisements about the serious harms of tobacco use: pre-testing results from 10 lowto middle-income countries. Tob Control. 2013 Jan;22(1):24-31. PMID:21994276

8. Ozcebe H. Birinci basamakta adolesan sorunlarına yaklasım [Approach to adolescent problems at first step]. Sted. 2002;11(10):374-7 (in Turkish).

9. Ling PM, Glantz SA. Why and how the tobacco industry sells cigarettes to young adults: evidence from industry documents. Am J Public Health. 2002 Jun;92(6):908-16. PMID:12036776
10. Josefson D. Tobacco company targeted marketing campaign at teenagers. BMJ. 1998 Jan 31;316(7128):330. PMID:9487163

11. McCarthy M. Tobacco companies must admit deceit in massive new advertising campaign. BMJ 2014;348:g266 (http:// dx.doi.org/10.1136/bmj.g266).

12. White V, Tan N, Wakefield M, Hill D. Do adult focused antismoking campaigns have an impact on adolescents? The case of the Australian National Tobacco Campaign. Tob Control. 2003 Sep;12 Suppl 2:ii23-9. PMID:12878770

13. Turkish Statistical Institute (TURKSTAT). Population Database based on 2013 (https://biruni.tuik.gov.tr/ medas/?kn=95\&locale=tr, accessed 23 December 2013).

14. Farrelly MC, Davis KC, Yarsevich JM, et al. American Legacy Foundation, Getting to the Truth: Assessing Youths' Reactions to the truth and" think. Don't Smoke" Tobacco Countermarketing Campaigns. 2006 (http://escholarship.org/uc/ item/249139nm\#page-1, accessed 31 August 2016).

15. HEALTH ROTMO. 4207 Sayılı Tütün Ürünlerinin Zararları Önlenmesi ve Kontrolü Hakkında Kanun (Law 4207, "The Prevention and Control of Harm from Tobacco Products") (http:// www.mevzuat.gov.tr/MevzuatMetin/1.5.4207-20130524.pdf, accessed 23 December 2013).

16. Bland JM, Altman DG. Cronbach's alpha. BMJ. 1997 Feb 22;314(7080):572. PMID:9055718

17. Biener L, Ji M, Gilpin EA, Albers AB. The impact of emotional tone, message, and broadcast parameters in youth anti-smoking advertisements. J Health Commun. 2004 MayJun;9(3):259-74. PMID:15360037

18. Schar E, Gutierrez K, Murphy-Hoefer R, et al. Tobacco use prevention media campaigns: lessons learned from youth in nine countries. Atlanta: US Centers for Disease Control and Prevention, National Center for Chronic Disease Prevention and Health Promotion, Office of Smoking and Health; 2006 (https://stacks.cdc.gov/view/cdc/11400, accessed 31 August 2016).

19. Preventing tobacco use among youth and young adults. A report of the Surgeon General. Atlanta, GA: U.S. Department of 
Health and Human Services, Centers for Disease Control and Prevention, National Center for Chronic Disease Prevention and Health Promotion, Office on Smoking and Health; 2012 (http://www.surgeongeneral.gov/library/reports/preventing-youth-tobacco-use/full-report.pdf, accessed 31 August 2016).

20. Cotter T, Hung WT, Perez D, Dunlop S, Bishop J. Squeezing new life out of an old Sponge: how to modernise an antismoking media campaign to capture a new market. Aust N ZJ Public Health. 2011 Feb;35(1):75-80. PMID:21299705

21. Pechmann C, Reibling ET. Anti-smoking advertising campaigns targeting youth: case studies from USA and Canada. Tob Control. 2000;9 Suppl 2:ii18-31. PMID:10841588

22. Wakefield M, Flay B, Nichter M, Giovino G. Effects of antismoking advertising on youth smoking: a review. J Health Commun. 2003 May-Jun;8(3):229-47. PMID:12857653

23. Vardavas Cl, Connolly G, Karamanolis K, Kafatos A. Adolescents perceived effectiveness of the proposed European graphic tobacco warning labels. Eur J Public Health. 2009 Apr;19(2):212-7. PMID:19218335

24. Biener L, Siegel M. Tobacco marketing and adolescent smoking: more support for a causal inference. Am J Public Health. 2000 Mar;90(3):407-11. PMID:10705860

25. Pathania VS. Women and the smoking epidemic: turning the tide. Bull World Health Organ. 2011 Mar 1;89(3):162. 10.2471/ BLT.11.086389 PMID:21379407
26. Hitchman SC, Fong GT. Gender empowerment and female-tomale smoking prevalence ratios. Bull World Health Organ. 2011 Mar 1;89(3):195-202. PMID:21379415

27. Amos A, Haglund M. From social taboo to "torch of freedom": the marketing of cigarettes to women. Tob Control. 2000 Mar;9(1):3-8. PMID:10691743

28. Mackay J, Eriksen M. The tobacco atlas. Geneva: World Health Organization; 2002 (http://www.who.int/tobacco/resources/publications/tobacco_atlas/en/, accessed 31 August 2016).

29. Reichert VC, Seltzer V, Efferen LS, Kohn N. Women and tobacco dependence. Obstet Gynecol Clin North Am. 2009;36(4):87790. PMID:19944306

30. Fronczak A, Polańska K, Makowiec-Dabrowska T, Kaleta D. Palenie tytoniu wśród kobiet - strategie dla ograniczenia epidemii tytoniowej. [Smoking among women-strategies for fighting the tobacco epidemic]. Przegl Lek. 2012;69(10):1103-7 (in Polish). PMID:23421100

31. Hiscock R, Bauld L, Amos A, Fidler JA, Munafò M. Socioeconomic status and smoking: a review. Ann N Y Acad Sci. 2012 Feb;1248:107-23. PMID:22092035

32. Scragg R, Glover M, Paynter J, Wong G, McCool J. Association of parent and best friend smoking with stage of adolescent tobacco smoking. N Z Med J. 201011 26;123(1326):77-87. PMID:21326402 